\title{
APPLICATION OF SCHEFFE'S MODEL FOR STABILIZATION OF AMURO- OKIGWE SUBGRADE USING MALE INFLORESCENCE OF OIL PALM ASH
}

\author{
O. A. Oguaghamba ${ }^{1, *}$ F. O. Okafor ${ }^{2}$ and V. C. Anokwute ${ }^{3}$

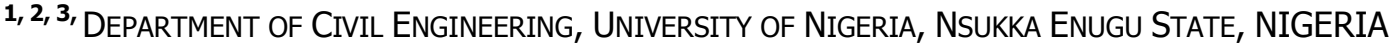 \\ E-mail addresses: ${ }^{1}$ onyedikachi.oguaghamba@unn.edu.ng, ${ }^{2}$ fidelis.okafor@unn.edu.ng, \\ 3 brandyvictor3@gmail.com
}

\begin{abstract}
This paper presents the use of non-conventional, renewable (sustainable) and locally available material in the form of vegetable fibre sourced from palm oil tree (Male Inflorescence of Oil Palm Ash; MIPA) for expansive soil improvement. Expansive soil subgrade of Imo - Clay Shale formation traversing Amuro - Okigwe section of Owerri - Okigwe road were identified for its intermittent flexible pavement failure. Samples of this subgrade were mixed with MIPA at varying proportions in line with the Scheffe's model approach to improve the natural engineering properties of the soil. Hence, MIPA - Amuro subgrade stabilization models for the maximum dry density (MDD) and California bearing ratio (CBR) were developed. These models showed good correlations with the experimental results in the control tests, as they possess less than 3\% differences. For 5\% significance value, $a$, and 2 degrees of freedom; the $t$ - value obtained from the standard statistical table, $t_{(\alpha / N)}\left(v_{e}\right)$ is 5.78. This value is greater than the $t$-values obtained in the experimental and model results of the control experiment. Similarly, the F- value obtained from the standard statistical table, is 19.00. This value is greater than the $F$ - value obtained between the experimental results and model results in an independent control experiment for CBR response. It is slightly differed for MDD response towards the right extremum. The deviation is however minor, as the left extremum condition is very satisfactory. Hence, the slight inconsistency allowed, having satisfied by the Student's $t$ - Test. The inverse of this statistical $F$ value is 0.0526, which is also smaller than any of the $F$ - value obtained. Based on statistical significance level, the Null hypothesis is accepted. Hence, the model is adequate. In the CBR results, 10.5\% MIPA content in the soil gives the greatest strength (CBR value) of 8.13KN, which is about 31\% increase in strength from $6.21 \mathrm{KN}$ of natural CBR. When MIPA content in the modified soil is in excess (about or greater than 11\%), the CBR value of modified soil begins to reduce.
\end{abstract}

Keywords: Mixture Design, Simplex Lattice, Amuro - Okigwe, Subgrade, MIPA, Scheffe's Model

\section{INTRODUCTION}

Pavement failure occurs when an asphalt surface no longer holds its original shape and develops material stress which causes issues. Pavement failure issues include cracking, potholes, depressions, rutting, shoving, upheavals, and raveling [1]. Figure 1 shows a flexible pavement cracking failure.

The Owerri-Okigwe road in Imo state is a 59kilometer stretch highway constructed by the Federal Government, over three decades ago. It is the major link between Owerri, Okigwe, Enugu, Abia and Ebonyi State. Motorists and commuters are terribly lamenting the horrible state of this road. Federal Road Maintenance Agency from time to time engage contractors who do remedial work on the road. Such work involves removing and replacing the defective pavement and surfacing or base material. The defective area are covered or seal with an overlay of a suitable material to renew the surface.

* Corresponding author, tel: +234-806-086-9002 


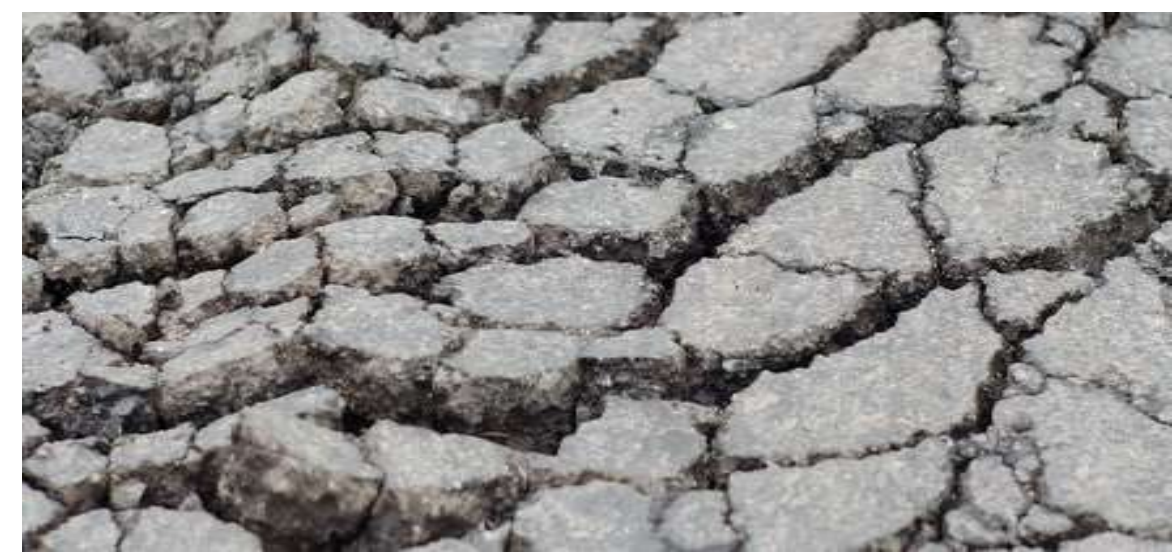

Figure 1: Flexible pavement cracking failure

Source: Lone Star Paving (https://www.lonestarpavingtx.com) [1].

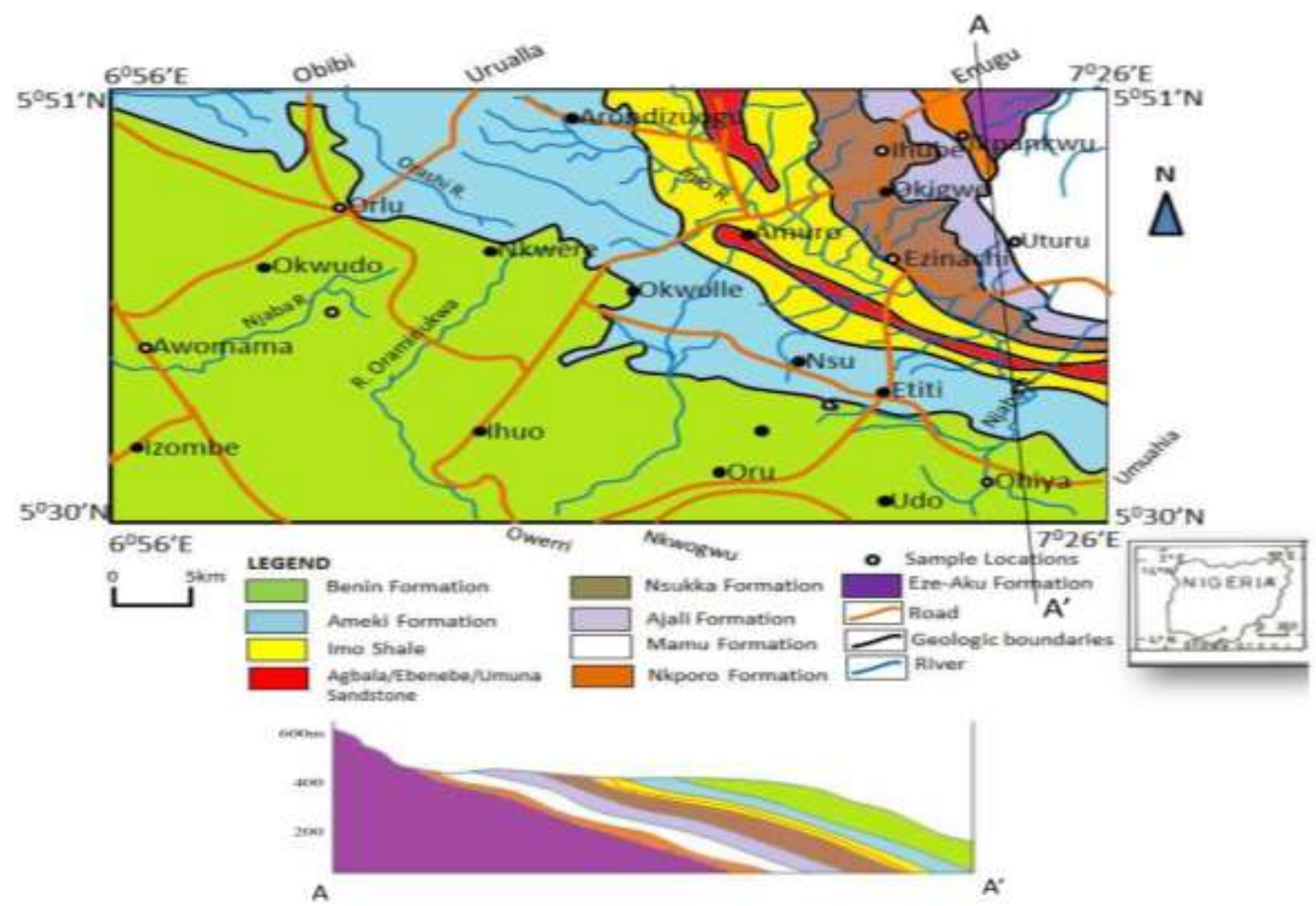

Figure 2: Geological map of the study area

Source: Mineralogical and geochemical properties of clay deposits in parts of Southeastern Nigeria, [4]

Sometimes, the defective pavement and unstable surfacing materials are removed down to a stable base before overlaying with new materials. Sooner than later these remedial works are done, pot holes and rutting usually resurface.

The consistent failure of the road along Amuro Okigwe axis may not be unconnected with underlying subgrade materials, among other factors. Amuro Okigwe has Imo clay shale as its parent material (Figure 2). Obeta and Njoku [2] reported that Okereke and others [3] described the Imo formation to consist of a thick clayey shale which is fine textured and dark to bluish grey. It sometimes contains an admixture of clay and stone with a thin band of carbonized plant remains but becomes more sandy towards its top where it consists of bands of sandstone and shale.

However, de Graft-Johnson and others [5] according to Manasseh and Agbede [6] defined shale as highly consolidated clays, silts and sands or a mixture of all three fractions of soil derived from the weathering of rocks. These fractions of soil, they reported are 
deposited in sea or riverbeds in layers and subjected to high overburden pressures, which lead to consolidation and diagenesis. Clays are secondary materials created from granite, feldspar, and other materials that break apart, decompose or have undergone chemical changes to form clay. Common clay minerals are kaolinite, illite, and montmorillonite. Clays are predominantly expansive soils, which are troublesome soils in road cuts and other construction. It is a notoriously unpredictable material, which exhibit generally undesirable engineering properties. Depending on the soil's content in which it is found, clay can appear in various colours from white to dull gray or brown to deep orange-red. They tend to have low shear strengths and to lose shear strength further upon wetting or other physical disturbances. They can be plastic and compressible and they expand when wetted and shrink when dried. As cohesive soils, they can creep overtime under constant load, especially when the shear stress is approaching its shear strength, making them prone to sliding. They develop large lateral pressures. They tend to have low resilient modulus values. For these reasons, clays are generally poor materials for foundations [6] and [7].

The subgrade is a layer of natural soil (about $60 \mathrm{~cm}$ below the top) prepared to receive the layers of the pavement. The subgrade should possess the required geotechnical properties (in terms of bearing capacity, tensile strength, compressive strength, CBR, optimum moisture content (OMC), MDD, overall performance and among others) to take up the stresses imposed due to loads without shear failure or excessive deformation. When the soil engineering characteristics are not met, the soil are subjected to modification or improvement. This engineering technique is known as soil stabilization.

Soil stabilization in road construction is generally defined as any physical, chemical, or combined method, etc. used to change a natural soil to meet an engineering purpose [8] and [9]. The physical method of soil stabilization is called mechanical stabilization. Its process alters the soil properties by changing the gradation through soil replacement, mixing with other soils, densifying the soil using compaction efforts, or undercutting the existing soil and replacing them with granular material. This option is usually not feasible considering the local economic factors.

Chemical Stabilization is the transformation of soil index properties by adding chemical additives such as
Portland cement, fly ash, cement kiln dust, furnace slag, bauxite slag, lime, blast furnace slag, asbestos cement, bitumen among others, often to alter the physical and chemical properties of the soil including the cementation of the soil particles. Stability is achieved by (a) increasing the soil particle size by cementation, internal friction among the agglomerates, greater shear strength, reduction in the plasticity index, and reduced shrink/swell potential. (b) absorption and chemical binding of moisture that will facilitate compaction [2].

Ola [11] used a combination of lime and cement in varying percentages to treat black cotton soils of Northeastern Nigeria and recorded improvement in strength properties as the 7-day unconfined compressive strength (UCS) and CBR value of black cotton soil increased from $210 \mathrm{kN} / \mathrm{m}$ and $2 \%$ for the natural soil to $1350 \mathrm{kN} / \mathrm{m}$ and $140 \%$ respectively at $10 \%$ lime $+8 \%$ cement. This combination also gave the highest Compressive strength. Maximum swell from CBR tests for the various combinations showed that lime primarily prevents road base from swelling while the primary function of cement is to increase the strength of the base course material.

Osinubi [12] reported improvement in strength properties of black cotton soil when cement and lime were employed for stabilization. The 7-day UCS and CBR values increased from $100 \mathrm{kN} / \mathrm{m}$ and $5 \%$ for the natural soil to $1885 \mathrm{kN} / \mathrm{m}$ and $70 \%$ respectively at 4 $\%$ lime $+10 \%$ cement. Katti and Katti [13] reported similar improvement when cement-lime admixture was used to treat black cotton soil of India.

Osula [14] showed that CBR value of $50 \%, 80 \%$ and $130 \%$ were obtained respectively when $6 \%, 8 \%$ and $12 \%$ cement was used to treat laterite with no lime added. In another study [14], the addition of $6 \%$ cement and 3\% lime, $8 \%$ cement and 2\% lime, $8 \%$ cement and $3 \%$ lime gave CBR values of $70 \%, 80 \%$ and $95 \%$, respectively.

Notwithstanding, the selection of materials for stabilization is mainly determined by cost and available facilities for production and processing. Industrialized chemical materials, such as Portland cement and Lime are utilized in practically all civil engineering construction sites all over the world; and hence are not sustainable. That is, their use would compromise the environment or deplete the materials for future generations. They do not incorporate sustainability into their practice in order to improve the quality of life. 
However, industrial by products such as: fly ash, cement kiln dust, blast furnace slag, silica fumes, red mud, marble dust among others are partially sustainable engineering stabilization materials to extent. This is so because, they are waste materials of natural occurring construction materials, hence, their use reduces the rate of demand for these pure construction materials.

According to [7]; and Arora and Aydilek [15] applied fly ash for stabilizing expansive clays. In their findings, 15 to $30 \%$ of fly ash improved the UCS and CBR values of expansive soils. Brooks [7] upgraded expansive soil as a construction material using Rice husk ash (RHA) and fly ash, which are waste materials. Stress strain behavior of unconfined compressive strength showed that failure stress and strains increased by $106 \%$ and $50 \%$ respectively with RHA content of $12 \%$ and a fly - ash content of $25 \%$, Unconfined Compressive Stress increased by $97 \%$ while CBR improved by $47 \%$.

The availability of non-conventional, renewable and local materials such as vegetable fibres (oil palm, sisal, coconut, piassava, jute, fique, bamboo, banana fibre, bagasse of sugar cane, sugarcane straw ash, curaua; pulp of bamboo, eucalyptus, coconut;) are presently being utilized for soil improvement. Other forms of non - conventional materials are the agricultural waste such as: palm fruit fibre, rice husk, palm oil bunch, male inflorescence of oil palm ash, saw dust from saw mills, rice husk, groundnut husk, corncob, coconut shell and so forth. These materials are within reach, lead to save in cost of project. Their use has attendant reduction in waste production and consequent conservation of the environment. They sustain the environment when replaced or substituted with their counterpart conventional materials, which on their own are hazardous to human health. Example is asbestos cement. Other

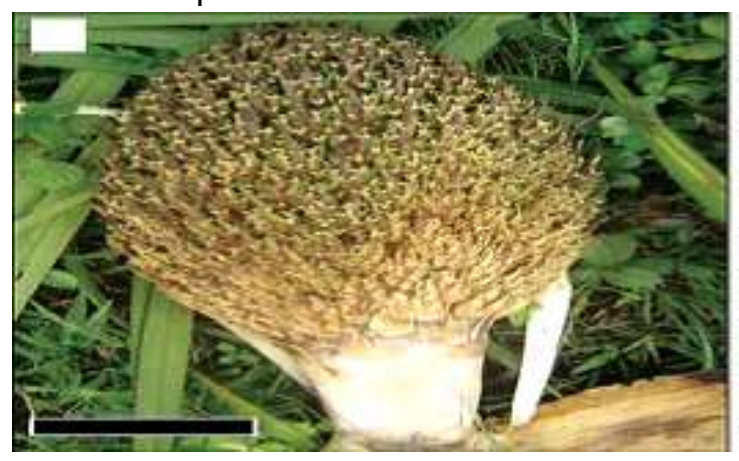

(A) Mature female inflorescence merits of these renewable materials are lower emission indices of pollution and energetic consumption. The disposal of these agricultural waste materials without putting them in use would no doubt constitute environmental challenge [2].

Therefore, with the need for urgent reconstruction of the Amuro - Okigwe axis of Owerri - Okigwe road and in the light of scarce desirable subgrade materials in the area, any effort towards finding sustainable and economical alternative subgrade improvement techniques to the subgrade soils of that locality is encouraged.

\subsection{Inflorescence of Oil Palm (Elaeis guineensis Jacq.)}

The inflorescence, also called flower cluster, in its early stages is enclosed in a hard-covering envelope known as spathe which spits open as the flowers mature exposing the entire inflorescence for pollination purpose. The spathe protects the delicate flowers from being shriveled up by the intense heat until these are mature and ready to perform their function. The spathe at the beginning is greenish, becoming brown when near splitting, where their splitting is longitudinal. The oil palm normally produces functionally unisexual male and female inflorescences in an alternating cycle, thereby minimizing the chances of self-pollination. Macroscopic views of the normal male and female inflorescences are shown in Figure 3. The male spathes are shorter and wider than the female ones. Each spikelet carries a large number of tiny flowers as many as 8,000 to 10,000 in female and more in male inflorescence. The annual number of spathes born by a palm varies from none to about 25 in females and to even more in males, but the average is a dozen for females and more for males [3].

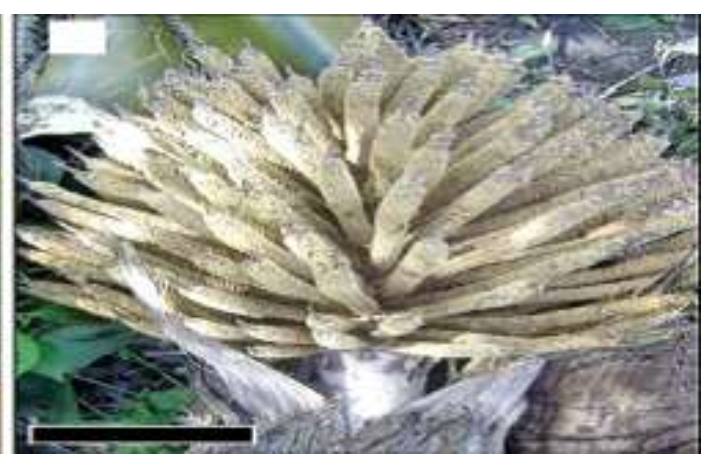

(B) Mature male inflorescence

Figure 3: Macroscopic views of oil palm inflorescences

Source: Environmental regulation of sex determination in oil palm: current knowledge and insights from other species [17] 


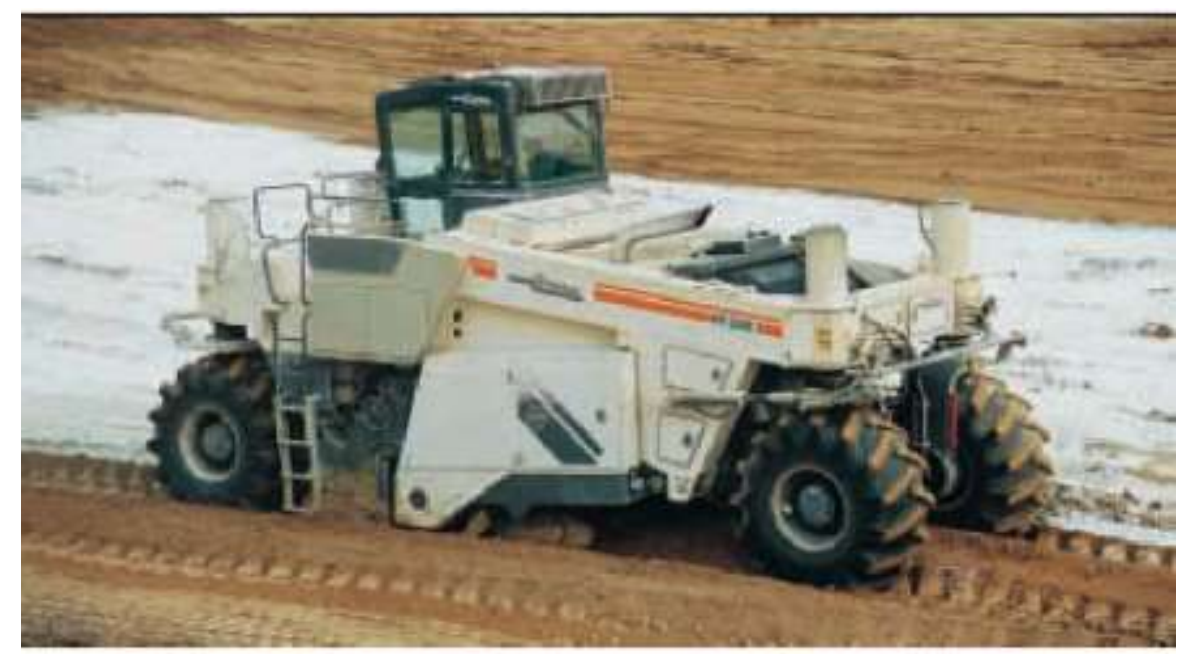

Figure 4: Road construction equipment embarking on subgrade stabilization Source: Characterization and improvement of soils and materials session [18].

Male inflorescence of oil palm does not produce any fruit unlike female inflorescence that produces both fruit and kernel. Its ash, MIPA is organic Potash, in Igbo dialect referred to as "Ngu", which is used in making native delicacies such as Abacha, Ugba, Nkwobi and Isi Ewu. It is a good substitute for industrial potash, Crystal Potash (granular POTASH is the crystallized hydrous carbonate of potassium $\mathrm{K}_{2} \mathrm{CO}_{3} \cdot \mathrm{H}_{2} \mathrm{O}$ ); as it is similar in composition with powdery anhydrous Pearl Ash $\mathrm{K}_{2} \mathrm{CO}_{3}$ ).

Male inflorescence of oil palm ash, however attracted more attention due to environmental pollution and an increasing interest in conservation of energy and resources. These waste materials, are not only socially acceptable but easily available. The effect of using MIPA as a partial replacement for cement has been investigated in this research.

In view of this, an experimental programme was undertaken to find the characteristics variations on mixing the male inflorescence of oil palm ash and clay in locally available Amuro - subgrade soil, to attain significant gain in engineering and supporting characteristics for subgrade construction.

Scheffe's mathematical model that would encourage wide application of soil improvement techniques are sought to provide reference and ratios to the construction industries on the use of the available soil and the agricultural (MIPA) to the enhancement of engineering properties of soils. Figure 4 shows an equipment grading the subgrade and embarking on stabilization process to achieve homogenous mix during a road construction project.

\subsection{Mixture Designs}

When a product is formed by mixing together two or more ingredients, the product is called a mixture, and the ingredients are called mixture components. In a general mixture problem, the measured response is assumed to depend only on the proportions of the ingredients in the mixture, not the amount of the mixture [19].

According to Oguaghamba and Mama [20], mixture design may be defined as the process of selecting suitable mix ingredients (or components) and their relative proportions with the aim of producing desired mixture responses and characteristics. There are several different types of mixture designs. The most common ones are simplex lattice, simplex centroid, simplex axial and extreme vertex designs, each of which is used for a different purpose. Simplex lattice mixture design gives better understanding of the shape of the response surface when the natural choice for design points are spread evenly over the whole simplex. It is ordered in arrangement consisting of a uniformly spaced distribution of points on a simplex [20].

In mixture experiments, the levels of individual components of the mixture are not independent [21]. Assuming the mixture to be a unit quantity, then the sum of all proportions of the component must be unity. That is,

$$
\begin{gathered}
\left.\mathrm{X}_{1}+\mathrm{X}_{2}+\ldots+\mathrm{X}_{\mathrm{q}-1}+\mathrm{X}_{\mathrm{q}}=1 \quad \text { (i. e } 100 \%\right) \\
\left.\sum_{i=1}^{q} \mathrm{x}_{\mathrm{i}}=1 \quad \text { (i. e } 100 \%\right)
\end{gathered}
$$

Thus, Equation (4) implies that $X_{i}$ component of the mixture is within the limits: 


$$
0 \leq X_{i} \leq 1
$$

1.3 Simplex Designs and Pseudo - Components The coordinate system used for the proportion of ingredients, $X_{i},(i=1,2, q)$ in a mix design is called a simplex coordinate system. $q$ is the number of ingredients in each experimental run (or design space lattice or point). Oguaghamba and Mama [20] defined the simplex coordinate system, $X_{i}$ as:

$$
\mathrm{X}_{\mathrm{i}}=0, \frac{1}{\mathrm{~m}}, \frac{2}{\mathrm{~m}}, \cdots, 1
$$

where, $\mathrm{m}$ is degree of the lattice (or dimensional space).

They gave the expressions of dimension or space of any space lattice and the number of design space points, $\mathrm{N}$ in a $\{\mathrm{q}, \mathrm{m}\}$ simplex lattice design as in Equations (4) and (5):

$$
N=\frac{(q+m-1) !}{m !(q-1) !}
$$

whereas, the number of for $(i \neq j=1,2,3, \ldots, q)$; $D$ $=$ Dimension of Lattice

\subsection{Pseudo - components in Mixture Design}

In mixture design, Pseudo - components are referred to as imaginary or coded variables used to simplify design construction and model fitting, thereby reducing the correlation between component bounds in constrained designs. The values or proportions of the Pseudo - components in a mixture design is determined using the expression of the simplex coordinate system, $X_{i}$. The Pseudo - components variable would contain only the variables obtain in $X_{i}$ [20].

Figure 5 and Table 1 shows the number of design space points and dimension of $\{3,2\}$ ( 3 - variables or ingredients and 2 - dimensional) space lattice obtained using Equations (3), (4) and (5).

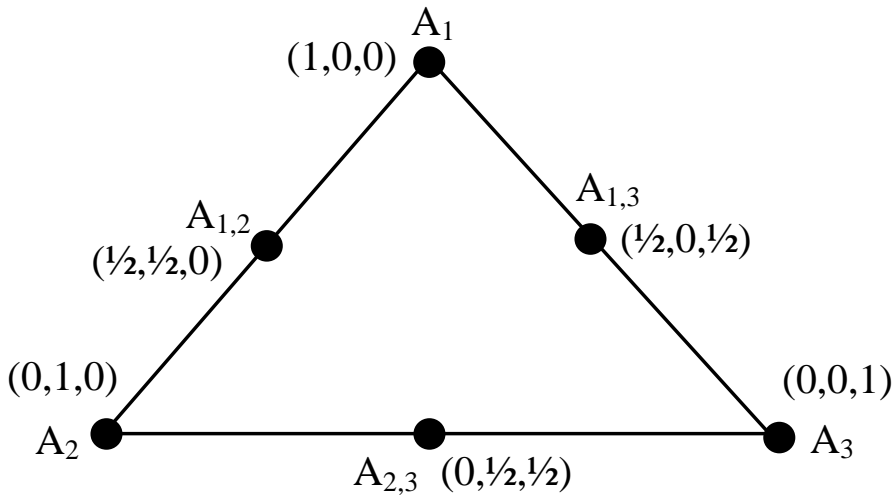

(a) 2 -dimensional $\{3,2\}$ Lattice Design
Pseudo - components rescale the constrained data area so that the minimum amount allowed (the lower bound) of each component is zero in mixture design as in Scheffe's model.

\section{MATERIALS AND METHODS}

\subsection{Study Area}

The study area, which lies within the geographical coordinates of Latitude of $5.798383^{\circ}\left(5^{\circ} 47^{\prime} 54.18^{\prime \prime}\right)$ $\mathrm{N}$ and Longitude of $7.297736^{\circ}\left(7^{\circ} 17^{\prime} 51.85^{\prime \prime}\right) \mathrm{E}$ is located in Amuro, Okigwe LGA of Imo State, Nigeria. On the World Geodetic System (WGS) 1984 Universal Traverse Mercator (UTM) Zone $32 \mathrm{~N}$, it is situated on Northing $641257.35 \mathrm{~m} \mathrm{~N}$ and Easting on 311507.45 $\mathrm{m}$ E, height $100 \mathrm{~m}$. Amuro - Okigwe has Imo clay shale as its parent material.

Imo state lies within the humid tropics. Temperatures are high and change slightly during the year (mean daily temperature about 27) [4]. The average annual rainfall is about $2400 \mathrm{~mm}$ and there is a distinct dry season of about 3-month dryness. The State has rainforest vegetation characterized by multiple tree species. Agriculture is a major socio-economic activity in the study area. Agricultural crops mostly cultivated in the study area include yam (Dioscorea Spp), cassava (Manihot Spp), oil palm (Elaies guineensis) and maize (Zea mays).

\subsection{Field Sampling}

The soil samples were collected from Ekeoha village in Amuro, Okigwe local government Area, Imo State. . It was collected at a depth of about $4 \mathrm{~m}$ apart using the hand auger and shovel below surface level from the hand auger, the sample was transferred to nylon coated sack bag to reduce loss of moisture.

\begin{tabular}{|ccc|}
\hline \multicolumn{3}{|c|}{ Table $1:(3,2)$ Space lattice points } \\
\hline $\begin{array}{c}\text { S/No } \\
(\mathrm{N})\end{array}$ & $\begin{array}{l}\text { Points of } \\
\text { Factors }\end{array}$ & $\begin{array}{c}\text { Pseudo } \\
\text { Components } \\
\left(\mathrm{X}_{\mathrm{i}}\right)\end{array}$ \\
\hline 1 & $\mathrm{~A}_{1}$ & $(1,0,0)$ \\
2 & $\mathrm{~A}_{2}$ & $(0,1,0)$ \\
3 & $\mathrm{~A}_{3}$ & $(0,0,1)$ \\
4 & $\mathrm{~A}_{12}$ & $(1 / 2,1 / 2,0)$ \\
5 & $\mathrm{~A}_{13}$ & $(1 / 2,0,1 / 2)$ \\
6 & $\mathrm{~A}_{23}$ & $(0,1 / 2,1 / 2)$ \\
\hline
\end{tabular}

Figure 5: Simplex Lattice Design 
The natural moisture content was determined after which it was air-dried. It was taken to the laboratory for examination and subsequent improvement for engineering use.

Male inflorescence of oil palm was collected from different palm oil trees in a different location at Okwe, in Onuimo Local Government Area, Imo State. It was incinerated into ash, Male Inflorescence of oil Palm Ash (MIPA) in a furnace at temperature of $400^{\circ} \mathrm{C}-500^{\circ} \mathrm{C}$ for about 2 hours; after which it was allowed to cool and taken to the laboratory for characterisation and experimental verification. The visual observation of the soil and MIPA samples are given in Table 2. Figure 6 is the pulverized MIPA.

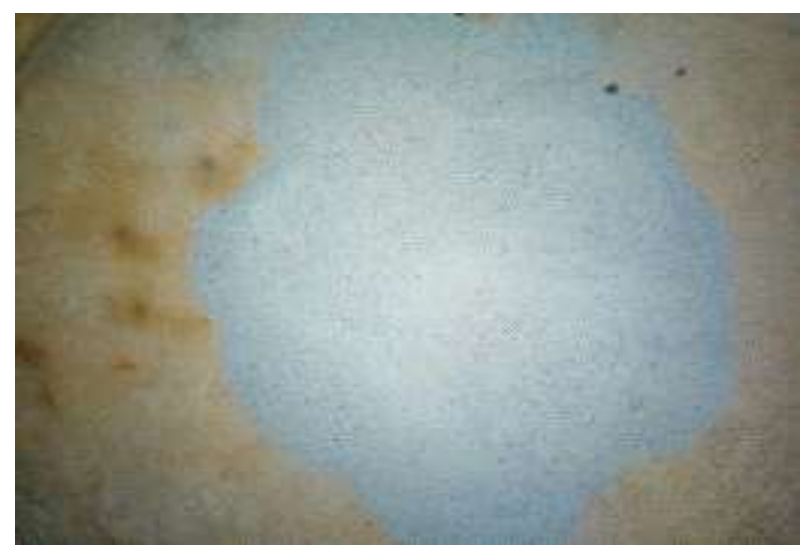

Figure 6: Pulverized MIPA

Table 2: Sample Physical Classifications

\begin{tabular}{lll}
\hline $\begin{array}{l}\text { Physical } \\
\text { classification }\end{array}$ & $\begin{array}{l}\text { Soil (4m below } \\
\text { ground level) }\end{array}$ & MIPA \\
\hline $\begin{array}{l}\text { Colour } \\
\text { Texture }\end{array}$ & $\begin{array}{l}\text { Reddish brown } \\
\text { Slightly of gravel }\end{array}$ & $\begin{array}{l}\text { Gray } \\
\text { Slight Course } \\
\text { Little harsh } \\
\text { when inhale at } \\
\text { Close range }\end{array}$ \\
\hline
\end{tabular}

\subsection{Laboratory Analyses}

The physical properties of the samples: Atterberg Limit Test, Specific Gravity Test, Particle Size Distribution were determined according to BS 1377: Part 2 : $1990: 4.3$ / 5.3, BS 1377: Part $2: 1990: 8.3$ and BS 1377: Part $2: 1990: 9.3$ respectively. The mechanical properties: Standard Compaction Test and CBR Test were determined according to BS 1377: Part 4: 1990: 3.3 / 3.5 and BS 1377: Part 4: 1990: 3.4, / 3.6. The determination of chemical substances and properties of the soil and MIPA samples were done in accordance with BS 1377: Part 3: 1990.

\subsection{Scheffe's Models}

Scheffe's models are most times referred to as the mixture models. They differ from the usual regression models due to the correlation between all the components in mixture designs. Another difference is that intercept term in the models is not included usually in the regression models.

\subsubsection{Relationship Between the Pseudo and Actual Components}

In Scheffe's mixture design, the Pseudo components, $X_{i}$ have relationship with actual components, $S_{i}$. The relationship between $\mathrm{X}$ and $\mathrm{S}$ as expressed by Scheffe [5] is given as:

$$
\begin{gathered}
\mathrm{X}=\mathrm{A} \cdot \mathrm{S} ; \mathrm{A}=\frac{\mathrm{X}}{\mathrm{S}} \text { or } \mathrm{A}=\mathrm{S}^{-1} \cdot \mathrm{X} ; \\
\mathrm{S}=\frac{\mathrm{X}}{\mathrm{A}}=\mathrm{X} \cdot \mathrm{A}^{-1}=\mathrm{S} \cdot \mathrm{B}
\end{gathered}
$$

Where,

$\mathrm{A}^{-1}=\mathrm{B} ; \quad \mathrm{A}$ is the of the actual - pseudo proportionality coefficient

Equation (6) is used to determine actual component of the mixture when the Pseudo components are known, vice versa.

For q components and in keeping with the principle of absolute volume, the sum of the actual component mixture in a given factor space is giving as:

$\mathrm{S}=\sum_{\mathrm{i}=1}^{\mathrm{q}} \mathrm{S}_{\mathrm{i}}=\mathrm{S}_{1}+\mathrm{S}_{2}+\mathrm{S}_{3}+\ldots+\mathrm{S}_{\mathrm{q}-1}+\mathrm{S}_{\mathrm{q}}=1$

Dividing Equation (7) by the sum of the actual component mixture gives:

$$
\begin{aligned}
& \bar{S}=\frac{S_{1}+S_{2}+S_{3}+\ldots+S_{q-1}+S_{q}}{S} \\
&=\frac{S_{1}}{S}+\frac{S_{2}}{S}+\frac{S_{3}}{S}+\ldots+\frac{S_{q-1}}{S}+\frac{S_{q}}{S} \\
& 1=Z_{1}+Z_{2}+Z_{3}+\ldots+Z_{q-1}+Z_{q}
\end{aligned}
$$

Where,

$\frac{\mathrm{S}_{1}}{\mathrm{~S}}=\mathrm{Z}_{1} ; \frac{\mathrm{S}_{2}}{\mathrm{~S}}=\mathrm{Z}_{2} ; \frac{\mathrm{S}_{3}}{\mathrm{~S}}=\mathrm{Z}_{3} ; \frac{\mathrm{S}_{\mathrm{q}-1}}{\mathrm{~S}}=\mathrm{Z}_{\mathrm{q}-1} ; \frac{\mathrm{S}_{\mathrm{q}}}{\mathrm{S}}=\mathrm{S}_{\mathrm{q}}$

Then, at ith factor space is given as:

$$
\mathrm{Z}_{\mathrm{i}}=\frac{\mathrm{S}_{\mathrm{i}}}{\mathrm{S}} \quad(\mathrm{i}=1,2,3 \ldots, \mathrm{q})
$$

Equation (9) is the proportion of the $i^{\text {th }}$ constituent component of any considered mixture design.

As in a general mixture problem, the measured response is assumed to depend only on the proportions of the ingredients in the mixture, not the amount of the mixture. Therefore, modelling, consequent on experimentation can be based on the actual and pseudo components. Thus, the 
transformation of the actual components, $S_{i}$ into actual ratio components, $Z_{i}$ is jettisoned [20].

Then, expressing the actual - pseudo proportionality coefficient expression Equation (6) in matrix form gives;

$$
[\mathrm{A}]=\frac{[\mathrm{X}]}{[\mathrm{S}]}=[\mathrm{S}]^{-1}[\mathrm{X}]
$$

Oguaghamba and Mama [20] developed this expression to mean the inverse or transpose matrix of the actual components corresponding to the pure blend Pseudo - components of space points as follows:

$$
\begin{aligned}
& {[\mathrm{A}]=[\mathrm{S}]^{-1}=[\mathrm{S}]^{\mathrm{T}}} \\
& {[A]=\left[\begin{array}{cccccc}
a_{1,1} & a_{1,2} & a_{1,3} & . & a_{1, q} \\
a_{2,1} & a_{2,2} & a_{2,3} & . & . & a_{2, q} \\
a_{3,1} & a_{3,2} & a_{3,3} & \cdot & \cdot & a_{3, \mathrm{q}} \\
\cdot & \cdot & \cdot & \cdot & \cdot & \cdot \\
\cdot & \cdot & \cdot & \cdot & \cdot & \cdot \\
\cdot & \cdot & \cdot & \cdot & \cdot & \cdot \\
a_{N, 1} & a_{N, 2} & a_{N, 3} & \cdot & \cdot & a_{N, q}
\end{array}\right]}
\end{aligned}
$$

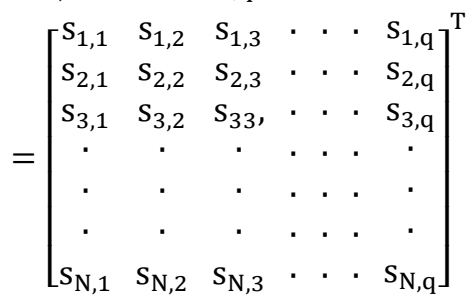

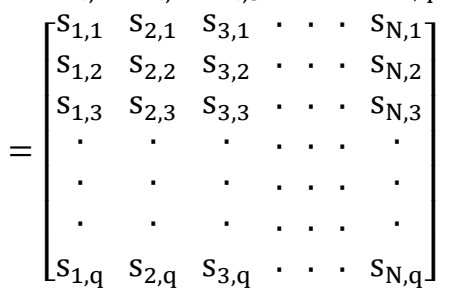

\subsubsection{Determination of Actual Components of the Nonlinear Blending Mixture, $\boldsymbol{S}_{N, q}^{\prime}$}

They gave the expression for the other actual components of the binary mixture, $\mathbf{S}_{\mathbf{N}, \mathbf{q}}^{\prime}$ for the remaining $\mathrm{N}-\mathrm{q}$ factor points as:

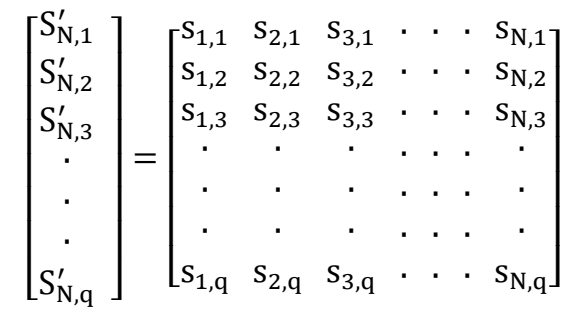

$$
\begin{aligned}
& \times\left[\begin{array}{lllll}
\mathrm{X}_{\mathrm{N}, 1} & \mathrm{X}_{\mathrm{N}, 2} & \mathrm{X}_{\mathrm{N}, 3} & \cdots & \mathrm{X}_{\mathrm{N}, \mathrm{q}}
\end{array}\right]^{\mathrm{T}} \\
& {\left[\mathrm{S}_{\mathrm{N}, \mathrm{q}}^{\prime}\right]=[\mathrm{A}] \cdot\left[\mathrm{X}_{\mathrm{N}, \mathrm{q}}\right]^{\mathrm{T}}=[\mathrm{S}] \cdot\left[\mathrm{X}_{\mathrm{N}, \mathrm{q}}\right]^{\mathrm{T}}}
\end{aligned}
$$

These derived actual components corresponding to the remaining $\mathrm{N}-\mathrm{q}$ lattice points of the pseudo components mixture proportions are used as other mixture proportion in the experimentation to obtain their corresponding responses.

\subsubsection{Generalized Scheffe's Second Degree Mathematical Models}

The standard form of the quadratic mixture model according to Scheffe [21] is given as:

Quadratic Model:

$$
E(y)=\sum_{i=1}^{q} \beta_{i} x_{i}+\sum \sum_{i<j}^{q} \beta_{i j} x_{i} x_{j}
$$

Where,

$\beta_{i}=$ linear blending portion due to the pure blend, $X_{i}$ $=1$ and $X_{j}=0 ; i \neq j \neq k ; E(y)=$ Expected response. $\beta_{i j}$ represents the quadratic nonlinear blending between component pairs, whose parameters may be either synergistic or antagonistic blending. $\beta_{i j k}$ represents the full cubic nonlinear blending among component sets of 3 , whose parameters may be either synergistic or antagonistic blending.

Oguaghamba and Mama [20] gave the generalized Scheffe's model for the second degree - $q$ variables mixture lattice $\{q, 2\}$ as follows:

$$
\begin{gathered}
\mathrm{E}(\mathrm{y})=\mathrm{y}_{1} \mathrm{x}_{1}\left(2 \mathrm{x}_{1}-1\right)+\mathrm{y}_{2} \mathrm{X}_{2}\left(2 \mathrm{x}_{2}-1\right) \\
+\mathrm{y}_{3} \mathrm{x}_{3}\left(2 \mathrm{x}_{3}-1\right)+\cdots \\
+\mathrm{y}_{\mathrm{q}-1} \mathrm{x}_{\mathrm{q}-1}\left(2 \mathrm{x}_{q-1}-1\right)+ \\
+\cdots+\mathrm{y}_{\mathrm{q}} \mathrm{x}_{\mathrm{q}}\left(2 \mathrm{X}_{q}-1\right)+4 \mathrm{y}_{12} \mathrm{x}_{1} \mathrm{x}_{2}+4 \mathrm{y}_{13} \mathrm{X}_{1} \mathrm{x}_{3} \\
+4 \mathrm{y}_{23} \mathrm{X}_{2} \mathrm{x}_{3} \\
+4 \mathrm{y}_{(\mathrm{q}-1), q} \mathrm{x}_{\mathrm{q}-1} \mathrm{x}_{\mathrm{q}}
\end{gathered}
$$

The term, $y_{i}$ and $y_{i j}$ correspond to the mixture response at the respective space points $i$ and $i j$ of the actual pure blend, $S_{i}$ for $i=1,2,3, \ldots, q$ (principal points); and derived actual binary blend, $\mathrm{S}_{\mathrm{ij}}$ (derived mix ratio) in Equation (19) obtained from the laboratory experiments.

\subsection{Model Validation and Adequacy}

Model validation is carried out in two ways, (a) either by randomly splitting an existing data set into two parts, and using part of the data for model fitting, and part of the data for model validation or (b) using one full data set for model fitting, and finding a second independent data set for model validation. The latter approach is adopted in Scheffe's model and validation [20].

Therefore, the model Equation (15) is tested for adequacy against the experimental results using a new set of design points. These new set of mixture design proportions (now referred to as control mixture design points) are determined in similar manner as the binary mixture proportions are determined in the main experiments. The only new 
set of parameters introduced are the control Pseudo - components.

Prior to this, a statistical hypothesis for this Scheffe's model would have been stated earlier. That is, the NULL HYPOTHESIS, $\mathrm{H}_{0}$ and the ALTERNATE HYPOTHESIS, $\mathrm{H}_{\mathrm{A}}$. Null hypothesis claims that there is no significant difference between specified Scheffe's model responses and the experimental responses for any other independent actual component mixtures (such as those of the control mixtures). Whereas, the alternate hypothesis is against the statement (i.e. there is significant difference between specified Scheffe's model responses and the experimental responses for any other independent actual component mixtures (such as those of the control mixtures)).

These hypotheses are tested at a specified significance level, a, which represents the maximum tolerable risk of incorrectly rejecting the null hypothesis, $H_{0}$. Tests used to check significant levels of difference between model and experimental responses include Student's $\mathrm{t}$ - test, Fisher's F - test, etc.

\subsubsection{Student's $t$ - Test Method}

The $t$ - test (also called Student's $t$ - Test) compares two "means" and tells if they are different from each other. The $t$ - test also defines how significant the differences are. In other words, it reveals if those differences could have happened by chance [20].

Oguaghamba and Mama [20] gave an advance and simpler expression for obtaining the $t$ - test variance in experimental response as follows:

$$
\mathrm{t}=\frac{\sqrt{(\mathrm{N}-1)} \times \sum\left(\mathrm{Y}_{\mathrm{m}}-\mathrm{Y}_{\mathrm{e}}\right)}{\sqrt{\left(\mathrm{N} \sum\left(\mathrm{Y}_{\mathrm{m}}-\mathrm{Y}_{\mathrm{e}}\right)^{2}-\left(\sum\left(\mathrm{Y}_{\mathrm{m}}-\mathrm{Y}_{\mathrm{e}}\right)\right)^{2}\right)}}
$$

where, $Y_{e}$ and $Y_{m}$ are the average experimental and model responses respectively; $\mathrm{N}$ is total design points in the control experiments, $t$ is the variance from the $\mathrm{t}$ - statistics.

The $t$ - value obtained in Equation (16) is compared with the one from the standard statistical table according to Dougherty [23] at enhanced $(\alpha / N)$ significant level and degree of freedom, $\mathrm{V}_{\mathrm{e}}$. That is, $t_{(\alpha / N)}\left(v_{e}\right)$. When the $\mathrm{t}-$ value from the standard statistical table, $t_{(\alpha / N)}\left(v_{e}\right)$ is greater than those of the t-values obtained in Equation (16), the Null hypothesis is accepted and the model is adequate. Otherwise, the Null hypothesis is rejected, the Alternate hypothesis is accepted and the model is not adequate.

\subsubsection{F - Statistics (Fisher's) Test Method}

This test compares the variance from the model response, $S_{i}$ with that from the experimental responses. The equation for Fisher's test is given as:

$$
\mathrm{F}=\frac{\text { explained variance }}{\text { unexplained variance }}=\frac{\mathrm{S}_{1}^{2}}{\mathrm{~S}_{2}^{2}}
$$

where,

$$
\begin{aligned}
\mathrm{S}_{1}^{2} \text { or } \mathrm{S}_{2}^{2}= & \mathrm{S}_{\mathrm{e}}^{2}=\frac{\sum\left(\mathrm{Y}_{\mathrm{e}}-\overline{\mathrm{y}}_{\mathrm{e}}\right)^{2}}{\mathrm{~N}-1} ; \mathrm{S}_{1}^{2} \text { or } \mathrm{S}_{2}^{2}=\mathrm{S}_{\mathrm{m}}^{2} \\
& =\frac{\sum\left(\mathrm{Y}_{\mathrm{m}}-\overline{\mathrm{y}}_{\mathrm{m}}\right)^{2}}{\mathrm{~N}-1} ; \overline{\mathrm{y}}_{\mathrm{e}}=\frac{\sum \mathrm{Y}_{\mathrm{e}}}{\mathrm{N}} ; \overline{\mathrm{y}}_{\mathrm{m}} \\
& =\frac{\sum \mathrm{Y}_{\mathrm{m}}}{\mathrm{N}}
\end{aligned}
$$

$\mathrm{S}_{1}{ }^{2}$ is the greater of $\mathrm{S}_{\mathrm{e}}{ }^{2}$ and $\mathrm{S}_{\mathrm{m}}{ }^{2} ; \mathrm{S}_{2}{ }^{2}$ is smaller of the $\mathrm{S}_{\mathrm{e}}{ }^{2}$ and $\mathrm{S}_{\mathrm{m}}{ }^{2} ; \mathrm{S}_{\mathrm{e}}{ }^{2}$ and $\mathrm{S}_{\mathrm{m}}{ }^{2}$ are variances from are experimental and model responses; $Y_{e}$ and $Y_{m}$ are experimental and model responses; $y_{e}$ and $y_{m}$ are mean values of experimental and model responses; $\mathrm{N}$ is the sample group or total control space points.

$\mathrm{N}-1=\mathrm{V}_{\mathrm{e}}$ (Degree of freedom of design points) (18) Fisher's's tests the adequacy of the model by comparing the responses of the experimental and model results in the control sample group. The Null Hypothesis is accepted and Alternative Hypothesis rejected if and only if:

$$
\frac{1}{\mathrm{~F}_{\alpha\left(\mathrm{v}_{1}, \mathrm{v}_{2}\right)}}<F<\mathrm{F}_{\alpha\left(\mathrm{v}_{1}, \mathrm{v}_{2}\right)}
$$

where, Dougherty [23] gave critical values of the $\mathrm{F}_{\alpha\left(\mathrm{v}_{1}, \mathrm{v}_{2}\right)}$ distribution in which $\alpha$ and $\mathrm{N}$ have their usual meaning; $v_{1}$ and $v_{2}$ are the number of degrees of freedom defined in Equation (18).

\section{SCHEFFE'S SECOND DEGREE MODEL FOR AMURO - OKIGWE CLAY SUBGRADE \\ 3.1 Model Formulation for Amuro - Okigwe Clay Subgrade}

On the strength of information of proportions of stabilizing additives, the actual mixture proportions in Table 3 were selected based on previous knowledge of use of additive in soil stabilization techniques. They form the building blocks for the Scheffe's model development. The pure blends of their pseudo components are assumed to correspond to these actual components.

Using Equation (13), the coefficient of the relationship of actual and a pseudo component in matrix form is obtained as: 
$[A]=[S]=\left[\begin{array}{lll}S_{1,1} & s_{1,2} & s_{1,3} \\ s_{2,1} & s_{2,2} & s_{2,3} \\ s_{3,1} & s_{3,2} & s_{3,3}\end{array}\right]^{T}=\left[\begin{array}{lll}s_{1,1} & s_{2,1} & s_{3,1} \\ s_{1,2} & s_{2,2} & s_{3,2} \\ s_{1,3} & s_{2,3} & s_{3,3}\end{array}\right]=$

$\left[\begin{array}{ccc}2 & 3 & 95 \\ 8 & 12 & 80 \\ 16 & 24 & 60\end{array}\right]^{T}=\left[\begin{array}{ccc}2 & 8 & 16 \\ 3 & 12 & 24 \\ 95 & 80 & 60\end{array}\right]$

From Equation (3), for second degree space lattice $(m=2)$, the simplex coordinate, $X_{i}$ is given, as:

$\mathrm{X}_{\mathrm{i}}=0, \frac{1}{\mathrm{~m}}, \frac{2}{\mathrm{~m}}, \cdots, 1 ; \mathrm{X}_{\mathrm{i}}=0, \frac{1}{2}, \frac{2}{2}, \cdots, 1=0,0.5$, and 1

In a three variable and second degree scheffe's polynomial and using Equation (5), the design space points is obtained as:
Design space points, $N=\frac{(\mathrm{q}+\mathrm{m}-1) !}{\mathrm{m} !(\mathrm{q}-1) !}=\frac{(3+2-1) !}{2 !(3-1) !}=6$ The remaining design space points to make up the six design space points are in the order of the coded variables are given in Table 4.

As in the control experiment, Oguaghamba and Mama [20] explained that the design space points are made of binary mixture and coded arbitrary but must be constrained to sum to unity. Design points 6 - 9 are added up to be used as control points.

Table 3: Pure blend Pseudo and Actual components for Scheffe's (3,2) Lattice

\begin{tabular}{ccccccccc}
\hline $\mathrm{N}$ & Points on Factor Space & \multicolumn{3}{c}{ Actual Components } & \multicolumn{3}{c}{ Pseudo Components } \\
\cline { 2 - 9 } & & $\mathrm{S}_{1}$ & $\mathrm{~S}_{2}$ & $\mathrm{~S}_{3}$ & $\mathrm{Y}$ Response & $\mathrm{X}_{1}$ & $\mathrm{X}_{2}$ & $\mathrm{X}_{3}$ \\
\hline 1 & $\mathrm{~A}_{1}$ & 2 & 3 & 95 & $\mathrm{Y}_{1}$ & 1 & 0 & 0 \\
2 & $\mathrm{~A}_{2}$ & 8 & 12 & 80 & $\mathrm{Y}_{2}$ & 0 & 1 & 0 \\
3 & $\mathrm{~A}_{3}$ & 16 & 24 & 60 & $\mathrm{Y}_{3}$ & 0 & 0 & 1 \\
\hline
\end{tabular}

Table 4: Binary blend Pseudo and Actual components for Scheffe's (3, 2) Lattice

\begin{tabular}{|c|c|c|c|c|c|c|c|c|}
\hline \multirow[t]{2}{*}{$\mathrm{N}$} & \multirow[t]{2}{*}{ Points on Factor Space } & \multicolumn{3}{|c|}{ Actual Components } & \multirow[t]{2}{*}{ Y Response } & \multicolumn{3}{|c|}{ Pseudo Components } \\
\hline & & $\begin{array}{c}\mathrm{S}_{1} \\
\mathrm{MIPA}\end{array}$ & $\begin{array}{c}\mathrm{S}_{2} \\
\text { Water }\end{array}$ & $\begin{array}{c}\mathrm{S}_{3} \\
\text { Soil }\end{array}$ & & $\begin{array}{c}\mathrm{X}_{1} \\
\text { MIPA }\end{array}$ & $\begin{array}{c}X_{2} \\
\text { Water }\end{array}$ & $\begin{array}{c}\mathrm{X}_{3} \\
\text { Soil }\end{array}$ \\
\hline 4 & $A_{12}$ & $\mathrm{~S}_{4,1}^{\prime}$ & $\mathrm{S}_{4,2}^{\prime}$ & $S_{4,3}^{\prime}$ & $Y_{1}$ & 0.5 & 0.5 & 0 \\
\hline 5 & $A_{13}$ & $S_{5,1}^{\prime}$ & $S_{5,2}^{\prime}$ & $S_{5,3}^{\prime}$ & $Y_{2}$ & 0.5 & 0 & 0.5 \\
\hline 6 & $\mathrm{~A}_{23}$ & $S_{6,1}^{\prime}$ & $S_{6,2}^{\prime}$ & $S_{6,3}^{\prime}$ & $Y_{3}$ & 0 & 0.5 & 0.5 \\
\hline \multicolumn{9}{|c|}{ Control Experiment } \\
\hline 7 & $C_{1}$ & $\mathrm{~S}_{7,1}^{\prime}$ & $\mathrm{S}_{7,2}^{\prime}$ & $\mathrm{S}_{7,3}^{\prime}$ & $C_{1}$ & 0.25 & 0.25 & 0.5 \\
\hline 8 & $\mathrm{C}_{2}$ & $S_{8,1}^{\prime \prime 1}$ & $\mathrm{~S}_{8,2}^{\prime, 2}$ & $\mathrm{~S}_{8,3}^{\prime \prime}$ & $\mathrm{C}_{2}$ & 0.25 & 0.5 & 0.25 \\
\hline 9 & $\mathrm{C}_{3}$ & $S_{9,1}^{\prime \prime}$ & $S_{9,2}^{\prime 2}$ & $S_{9,3}^{\prime}$ & $\mathrm{C}_{3}$ & 0.5 & 0.25 & 0.25 \\
\hline
\end{tabular}

Using Equation (18), the actual components of the binary Mixture, $S_{N, q}^{\prime}$ is obtained as follows:

$$
\begin{aligned}
& {\left[\begin{array}{l}
\mathrm{S}_{\mathrm{N}, 1}^{\prime} \\
\mathrm{S}_{\mathrm{N}, 2}^{\prime} \\
\mathrm{S}_{\mathrm{N}, 3}^{\prime}
\end{array}\right]=\left[\begin{array}{l}
\mathrm{S}_{1,1} \mathrm{~S}_{2,1} \mathrm{~S}_{3,1} \\
\mathrm{~S}_{1,2} \mathrm{~S}_{2,2} \mathrm{~S}_{3,2} \\
\mathrm{~S}_{1,3} \mathrm{~S}_{2,3} \mathrm{~S}_{3,3}
\end{array}\right] \times\left[\begin{array}{l}
\mathrm{X}_{\mathrm{N}, 1} \\
\mathrm{X}_{\mathrm{N}, 2} \\
\mathrm{X}_{\mathrm{N}, 3}
\end{array}\right]} \\
& {\left[\begin{array}{l}
\mathrm{S}_{4,1}^{\prime} \\
\mathrm{S}_{4,2}^{\prime} \\
\mathrm{S}_{4,3}^{\prime}
\end{array}\right]=\left[\begin{array}{ccc}
2 & 8 & 16 \\
3 & 12 & 24 \\
95 & 80 & 60
\end{array}\right] \times\left[\begin{array}{c}
0.50 \\
0.50 \\
0.00
\end{array}\right]=\left[\begin{array}{c}
5 \\
7.5 \\
87.5
\end{array}\right] ;\left[\begin{array}{c}
\mathrm{S}_{5,1}^{\prime} \\
\mathrm{S}_{5,2}^{\prime} \\
\mathrm{S}_{5,3}^{\prime}
\end{array}\right]=\left[\begin{array}{ccc}
2 & 8 & 16 \\
3 & 12 & 24 \\
95 & 80 & 60
\end{array}\right] \times\left[\begin{array}{c}
0.50 \\
0.00 \\
0.50
\end{array}\right]=\left[\begin{array}{c}
9 \\
13.5 \\
77.5
\end{array}\right]} \\
& {\left[\begin{array}{l}
\mathrm{S}_{6,1}^{\prime} \\
\mathrm{S}_{6,2}^{\prime} \\
\mathrm{S}_{6,3}^{\prime}
\end{array}\right]=\left[\begin{array}{ccc}
2 & 8 & 16 \\
3 & 12 & 24 \\
95 & 80 & 60
\end{array}\right] \times\left[\begin{array}{l}
0.00 \\
0.50 \\
0.50
\end{array}\right]=\left[\begin{array}{c}
12 \\
18 \\
70
\end{array}\right] ;\left[\begin{array}{c}
\mathrm{S}_{7,1}^{\prime} \\
\mathrm{S}_{7,2}^{\prime} \\
\mathrm{S}_{7,3}^{\prime}
\end{array}\right]=\left[\begin{array}{ccc}
2 & 8 & 16 \\
3 & 12 & 24 \\
95 & 80 & 60
\end{array}\right] \times\left[\begin{array}{c}
0.25 \\
0.25 \\
0.50
\end{array}\right]=\left[\begin{array}{c}
10.5 \\
15.75 \\
73.75
\end{array}\right]} \\
& {\left[\begin{array}{l}
\mathrm{S}_{8,1}^{\prime} \\
\mathrm{S}_{8,2}^{\prime} \\
\mathrm{S}_{8,3}^{\prime}
\end{array}\right]=\left[\begin{array}{ccc}
2 & 8 & 16 \\
3 & 12 & 24 \\
95 & 80 & 60
\end{array}\right] \times\left[\begin{array}{c}
0.25 \\
0.50 \\
0.25
\end{array}\right]=\left[\begin{array}{c}
8.5 \\
12.75 \\
78.75
\end{array}\right] ;\left[\begin{array}{l}
\mathrm{S}_{9,1}^{\prime} \\
\mathrm{S}_{9,2}^{\prime} \\
\mathrm{S}_{9,3}^{\prime}
\end{array}\right]=\left[\begin{array}{ccc}
2 & 8 & 16 \\
3 & 12 & 24 \\
95 & 80 & 60
\end{array}\right] \times\left[\begin{array}{c}
0.50 \\
0.25 \\
0.25
\end{array}\right]=\left[\begin{array}{c}
7 \\
10.5 \\
82.5
\end{array}\right]}
\end{aligned}
$$

With these pure and binary mixture proportions in Tables 3 and 4, as represented in Table 5, experimental tests are conducted the results are given as in Table 6. 
Table 5: Binary blend Pseudo and Actual components for Scheffe's (3, 2) Lattice

\begin{tabular}{|c|c|c|c|c|c|c|c|c|}
\hline \multirow[t]{2}{*}{$\mathrm{N}$} & \multirow[t]{2}{*}{ Points on Factor Space } & \multicolumn{3}{|c|}{ Actual Components } & & \multicolumn{3}{|c|}{ Pseudo Components } \\
\hline & & $\begin{array}{c}\mathrm{S}_{1} \\
\text { MIPA }\end{array}$ & $\begin{array}{c}\mathrm{S}_{2} \\
\text { Water }\end{array}$ & $\begin{array}{c}\mathrm{S}_{3} \\
\text { Soil }\end{array}$ & $\begin{array}{c}\mathrm{Y} \\
\text { Response }\end{array}$ & $\begin{array}{c}\mathrm{X}_{1} \\
\text { MIPA }\end{array}$ & $\begin{array}{c}\mathrm{X}_{2} \\
\text { Water }\end{array}$ & $\begin{array}{c}\mathrm{X}_{3} \\
\text { Soil }\end{array}$ \\
\hline 1 & $A_{1}$ & 2 & 3 & 95 & $Y_{1}$ & 1 & 0 & 0 \\
\hline 2 & $\mathrm{~A}_{2}$ & 8 & 12 & 80 & $Y_{2}$ & 0 & 1 & 0 \\
\hline 3 & $A_{3}$ & 16 & 24 & 60 & $Y_{3}$ & 0 & 0 & 1 \\
\hline 4 & $A_{12}$ & 5 & 7.5 & 87.5 & $Y_{12}$ & 0.5 & 0.5 & 0 \\
\hline 5 & $\mathrm{~A}_{13}$ & 9 & 13.5 & 77.5 & $Y_{13}$ & 0.5 & 0 & 0.5 \\
\hline 6 & $\mathrm{~A}_{23}$ & 12 & 18.0 & 70.0 & $Y_{23}$ & 0 & 0.5 & 0.5 \\
\hline \multicolumn{9}{|c|}{ Control Experiment } \\
\hline 7 & $\mathrm{C}_{1}$ & 10.5 & 15.75 & 73.75 & $\mathrm{C}_{1}$ & 0.25 & 0.25 & 0.5 \\
\hline 8 & $\mathrm{C}_{2}$ & 8.5 & 12.75 & 78.75 & $\mathrm{C}_{2}$ & 0.25 & 0.5 & 0.25 \\
\hline 9 & $\mathrm{C}_{3}$ & 7.0 & 10.50 & 82.50 & $\mathrm{C}_{3}$ & 0.5 & 0.25 & 0.25 \\
\hline
\end{tabular}

Table 6: Maximum dry density and California Bearing Ratio values corresponding to the design space points / lattice

\begin{tabular}{ccccc}
\hline $\mathrm{N}$ & $\begin{array}{c}\text { Points on } \\
\text { Factor Space }\end{array}$ & MDD $\left(\mathrm{Mg} / \mathrm{m}^{3}\right)$ & CBR Value $(\mathrm{KN})$ & $\begin{array}{c}\text { Scheffe's }(3,2) \text { Lattice } \\
\text { Coefficients, } \mathrm{y}_{\mathrm{i}} \text { and } \mathrm{y}_{\mathrm{ij}}\end{array}$ \\
\hline 1 & $\mathrm{~A}_{1}$ & 1.734 & 6.210 & $\mathrm{y}_{1}$ \\
2 & $\mathrm{~A}_{2}$ & 1.733 & 5.320 & $\mathrm{y}_{2}$ \\
3 & $\mathrm{~A}_{3}$ & 1.731 & 5.410 & $\mathrm{y}_{12}$ \\
4 & $\mathrm{~A}_{12}$ & 1.752 & 6.210 & $\mathrm{y}_{13}$ \\
5 & $\mathrm{~A}_{13}$ & 1.726 & 6.380 & \\
6 & $\mathrm{~A}_{23}$ & 1.726 & 8.240 & \\
7 & $\mathrm{C}_{1}$ & 1.732 & 7.810 & \\
8 & $\mathrm{C}_{2}$ & 1.733 & 7.710 & \\
9 & $\mathrm{C}_{3}$ & 1.730 & 6.730 & \\
\hline
\end{tabular}

For $\{3,2\}$, space lattice, for $q=3$, Equation (15) transforms as follows:

$\mathrm{E}(\mathrm{y})=\mathrm{y}_{1} \mathrm{X}_{1}\left(2 \mathrm{X}_{1}-1\right)+\mathrm{y}_{2} \mathrm{X}_{2}\left(2 \mathrm{X}_{2}-1\right)+\mathrm{y}_{3} \mathrm{X}_{3}\left(2 \mathrm{X}_{3}-1\right)+4 \mathrm{y}_{12} \mathrm{X}_{1} \mathrm{X}_{2}+4 \mathrm{y}_{13} \mathrm{X}_{1} \mathrm{X}_{3}+4 \mathrm{y}_{23} \mathrm{X}_{2} \mathrm{X}_{3}$

Substituting the coefficients, $y_{i}$ and $y_{i j}$ into Equation (20) gives:

$$
\begin{gathered}
\mathrm{y}_{M D D}=1.734 \mathrm{X}_{1}\left(2 \mathrm{X}_{1}-1\right)+1.733 \mathrm{X}_{2}\left(2 \mathrm{X}_{2}-1\right)+1.731 \mathrm{X}_{3}\left(2 \mathrm{X}_{3}-1\right)+4(1.752) \mathrm{X}_{1} \mathrm{X}_{2}+ \\
4(1.726) \mathrm{X}_{1} \mathrm{X}_{3}+4(1.726) \mathrm{X}_{2} \mathrm{X}_{3} \\
\mathrm{y}_{M D D}=1.734 \mathrm{X}_{1}\left(2 \mathrm{X}_{1}-1\right)+1.733 \mathrm{X}_{2}\left(2 \mathrm{X}_{2}-1\right)+1.731 \mathrm{X}_{3}\left(2 \mathrm{X}_{3}-1\right)+6.99 \mathrm{X}_{1} \mathrm{X}_{2}+ \\
6.956 \mathrm{X}_{1} \mathrm{X}_{3}+6.928 \mathrm{X}_{2} \mathrm{X}_{3} \\
\mathrm{y}_{C B R}=6.21 \mathrm{X}_{1}\left(2 \mathrm{X}_{1}-1\right)+5.32 \mathrm{X}_{2}\left(2 \mathrm{X}_{2}-1\right)+5.41 \mathrm{X}_{3}\left(2 \mathrm{X}_{3}-1\right)+4(6.21) \mathrm{X}_{1} \mathrm{X}_{2}+ \\
4(6.38) \mathrm{X}_{1} \mathrm{X}_{3}+4(8.24) \mathrm{X}_{2} \mathrm{X}_{3} \\
\mathrm{y}_{C B R}=6.21 \mathrm{X}_{1}\left(2 \mathrm{X}_{1}-1\right)+5.32 \mathrm{X}_{2}\left(2 \mathrm{X}_{2}-1\right)+5.41 \mathrm{X}_{3}\left(2 \mathrm{X}_{3}-1\right)+23.24 \mathrm{X}_{1} \mathrm{X}_{2}+ \\
29.24 \mathrm{X}_{1} \mathrm{X}_{3}+31.24 \mathrm{X}_{2} \mathrm{X}_{3}
\end{gathered}
$$

\subsection{Model Validation and Adequacy}

The variables for the Student's $\mathrm{t}$ - Test in Equation (16) are obtained and shown in Table 7. This followed the determination of the model and experimental results statistical significance.

Table 7: Student's $t$ - Test Variables

\begin{tabular}{ccccccccc}
\hline \multirow{2}{*}{$\mathrm{N}$} & \multicolumn{6}{c}{$\mathrm{MDD}\left(\mathrm{Mg} / \mathrm{m}^{3}\right)$} & \multicolumn{5}{c}{ CBR Value $(\mathrm{KN})$} \\
\cline { 2 - 9 } & $\mathrm{Y}_{\mathrm{e}}$ & $\mathrm{Y}_{\mathrm{m}}$ & $\mathrm{Y}_{\mathrm{m}}-\mathrm{Y}_{\mathrm{e}}$ & $\left(\mathrm{Y}_{\mathrm{m}}-\mathrm{Y}_{\mathrm{e}}\right)^{2}$ & $\mathrm{Y}_{\mathrm{e}}$ & $\mathrm{Y}_{\mathrm{m}}$ & $\mathrm{Y}_{\mathrm{m}}-\mathrm{Y}_{\mathrm{e}}$ & $\left(\mathrm{Y}_{\mathrm{m}}-\mathrm{Y}_{\mathrm{e}}\right)^{2}$ \\
\hline $\mathrm{C}_{1}$ & 1.728 & 1.739 & $-1.05 \mathrm{E}-02$ & $1.10 \mathrm{E}-04$ & 8.130 & 7.550 & 0.580 & 0.336 \\
$\mathrm{C}_{2}$ & 1.726 & 1.739 & $-1.26 \mathrm{E}-02$ & $1.59 \mathrm{E}-04$ & 6.850 & 7.131 & -0.281 & 0.079 \\
$\mathrm{C}_{3}$ & 1.739 & 1.741 & $-2.25 \mathrm{E}-03$ & $5.06 \mathrm{E}-06$ & 6.300 & 6.874 & -0.574 & 0.329 \\
\hline Sum & 5.193 & 5.218 & $-2.54 \mathrm{E}-02$ & $2.75 \mathrm{E}-04$ & 21.280 & 21.555 & -0.275 & 0.745 \\
\hline Mean & 1.731 & 1.739 & & & 7.093 & 7.185 & & \\
\hline
\end{tabular}

Therefore, 
$\mathrm{t}_{M D D}=\frac{\sqrt{(3-1)} \times\left(-2.54 \times 10^{-2}\right)}{\sqrt{\left(3 \times 2.75 \times 10^{-4}-\left(-2.54 \times 10^{-2}\right)^{2}\right)}}=-2.673 ;$

$\mathrm{t}_{C B R}=\frac{\sqrt{(3-1)} \times(-0.275)}{\sqrt{\left(3 \times 0.745-(-0.275)^{2}\right)}}=-0.265$

From the statistical tables [23]; at 5\% significance level, $\alpha ; 3$ control points and 2 degrees of freedom, $v_{e}$ (See Equation 18),

$t_{(\alpha / N)}\left(v_{e}\right)=t_{(5 \% / 3)}(2)=t_{(1.67 \%)}(2)=5.78$

The variables for the Fisher's F - Test in Equation (18) are obtained and shown in Table 8 for MDD response and Table 9 for CBR response of Amuro - subgrade when stabilized with MIPA.

Table 8: Fisher's F - Test Variables for MDD response

\begin{tabular}{|c|c|c|c|c|c|c|}
\hline \multirow[b]{2}{*}{$\mathrm{N}$} & \multicolumn{6}{|c|}{$\operatorname{MDD}\left(\mathrm{Mg} / \mathrm{m}^{3}\right)$} \\
\hline & $Y_{e}$ & $Y_{m}$ & $\mathrm{Y}_{\mathrm{e}}-\overline{\mathrm{y}}_{\mathrm{e}}$ & $\left(Y_{e}-\bar{y}_{e}\right)^{2}$ & $Y_{m}-\bar{y}_{m}$ & $\left(Y_{m}-\bar{y}_{m}\right)^{2}$ \\
\hline$C_{1}$ & 1.728 & 1.739 & $-3.00 \mathrm{E}-03$ & $9.00 \mathrm{E}-06$ & $-9.58 \mathrm{E}-04$ & $9.18 \mathrm{E}-07$ \\
\hline $\mathrm{C}_{2}$ & 1.726 & 1.739 & $-5.00 \mathrm{E}-03$ & $2.50 \mathrm{E}-05$ & $-8.33 E-04$ & $6.94 \mathrm{E}-07$ \\
\hline $\mathrm{C}_{3}$ & 1.739 & 1.741 & $8.00 \mathrm{E}-03$ & $6.40 \mathrm{E}-05$ & $1.79 \mathrm{E}-03$ & $3.21 \mathrm{E}-06$ \\
\hline Sum & 5.193 & 5.218 & & $9.80 \mathrm{E}-05$ & & 4.82E-06 \\
\hline Mean $(\bar{y})$ & 1.731 & 1.739 & & & & \\
\hline & $\mathrm{S}_{1}^{2}=\mathrm{S}_{\mathrm{e}}^{2}$ & $\frac{9.80 \times 10^{-}}{3-1}$ & $\begin{array}{l}4.90 \times 10^{-5} \\
{ }_{D}=\frac{\mathrm{S}_{1}^{2}}{\mathrm{~S}_{2}^{2}}=\frac{4 .}{2 .}\end{array}$ & $\begin{array}{l}5_{\mathrm{m}}^{2}=\frac{4.82}{3} \\
\frac{5}{6}=20.32\end{array}$ & $2.41 \times 10$ & \\
\hline
\end{tabular}

From the statistical tables [23]; at 5\% significance level, $\alpha$; and 2 degrees of freedom, $v_{e}$ (See Equation 18),

$$
\begin{gathered}
\mathrm{v}_{1}=\mathrm{v}_{2}=\mathrm{v}_{e}=2 ; \alpha=5 \% \\
\mathrm{~F}_{5 \%(2,2)}=19.00 ; \frac{1}{\mathrm{~F}_{5 \%(2,2)}}=0.0526 \\
\text { Hence, } 0.0526<20.32>19.0
\end{gathered}
$$

Table 9: Fisher's F-Test Variables for CBR response

\begin{tabular}{ccccccc}
\hline \multirow{2}{*}{$\mathrm{N}$} & \multicolumn{7}{c}{ CBR Value $(\mathrm{KN})$} \\
\cline { 2 - 7 } & $\mathrm{Y}_{\mathrm{e}}$ & $\mathrm{Y}_{\mathrm{m}}$ & $\mathrm{Y}_{\mathrm{e}}-\overline{\mathrm{y}}_{\mathrm{e}}$ & $\left(\mathrm{Y}_{\mathrm{e}}-\overline{\mathrm{y}}_{\mathrm{e}}\right)^{2}$ & $\mathrm{Y}_{\mathrm{m}}-\overline{\mathrm{y}}_{\mathrm{m}}$ & $\left(\mathrm{Y}_{\mathrm{m}}-\overline{\mathrm{y}}_{\mathrm{m}}\right)^{2}$ \\
\hline $\mathrm{C}_{1}$ & 8.130 & 7.550 & 1.037 & 1.0747 & 0.365 & 0.1332 \\
$\mathrm{C}_{2}$ & 6.850 & 7.131 & -0.243 & 0.0592 & -0.054 & 0.0029 \\
$\mathrm{C}_{3}$ & 6.300 & 6.874 & -0.793 & 0.6294 & -0.311 & 0.0969 \\
\hline Sum & 21.280 & 21.555 & \multicolumn{7}{c}{1.7633} & & 0.2330 \\
\hline Mean $(\bar{y})$ & 7.093 & 7.185 & & & & \\
\hline
\end{tabular}

$$
\begin{gathered}
\mathrm{S}_{1}^{2}=\mathrm{S}_{\mathrm{e}}^{2}=\frac{1.7633}{3-1}=0.882 ; \quad \mathrm{S}_{2}^{2}=\mathrm{S}_{\mathrm{m}}^{2}=\frac{0.2330}{3-1} \\
=0.1165 ;
\end{gathered}
$$

From the statistical tables [23]; at 5\% significance level, $\alpha$; and 2 degrees of freedom, $v_{e}$ (See Equation 18),

$$
\begin{gathered}
\mathrm{v}_{1}=\mathrm{v}_{2}=\mathrm{v}_{e}=2 ; \alpha=5 \% \\
\mathrm{~F}_{C B R}=\frac{\mathrm{S}_{1}^{2}}{\mathrm{~S}_{2}^{2}}=\frac{0.882}{0.1165}=7.568 \\
\mathrm{~F}_{5 \%(2,2)}=19.00 ; \frac{1}{\mathrm{~F}_{5 \%(2,2)}}=0.0526
\end{gathered}
$$

\section{Hence, $0.0526<7.568<19.0$}

This follows the determination of the model and experimental results statistical significance. The validation was achieved using a new set of design points referred to as control design points.

\section{RESULTS AND DISCUSSIONS}

Tables 10 and 11 show the chemical properties of Amuro - subgrade and MIPA samples; and the geotechnical properties of the soil sample used in this study respectively. 
Table 10: Chemical composition of male inflorescence of oil palm ash (MIPA)

\begin{tabular}{cccccc}
\hline Compound & Soil Sample & MIPA Sample & Compound & Soil Sample & MIPA Sample \\
\hline $\mathrm{Si}_{2} \mathrm{O}(\%)$ & 74.1403 & 54.4769 & $\mathrm{Ag}_{2} \mathrm{O}_{5}(\%)$ & 0.0156 & 0.0190 \\
$\mathrm{Al}_{2} \mathrm{O}_{3}(\%)$ & 14.0800 & 12.1922 & $\mathrm{NbO}(\%)$ & 0.0119 & 0.0139 \\
$\mathrm{Fe}_{2} \mathrm{O}_{3}(\%)$ & 9.3260 & 0.4434 & $\mathrm{PbO}(\%)$ & 0.0082 & 0.0100 \\
$\mathrm{TiO}_{2}(\%)$ & 0.7392 & 0.0726 & $\mathrm{RbO}(\%)$ & - & 0.0550 \\
$\mathrm{MgO}(\%)$ & 0.6109 & 4.0263 & $\mathrm{SO}_{2}(\%)$ & - & 2.5468 \\
$\mathrm{BaO}_{2}(\%)$ & 0.4600 & 0.2489 & $\mathrm{CuO}(\%)$ & - & 0.0234 \\
$\mathrm{~K}_{2} \mathrm{O}(\%)$ & 0.2607 & 21.6949 & $\mathrm{SrO}(\%)$ & - & 0.0685 \\
$\mathrm{CaO}(\%)$ & 0.1763 & 2.2512 & $\mathrm{P}_{2} \mathrm{O}_{5}(\%)$ & - & 1.4710 \\
$\mathrm{CdO}(\%)$ & 0.0849 & 0.1389 & $\mathrm{ZnO}(\%)$ & - & 0.0392 \\
$\mathrm{MnO}(\%)$ & 0.0458 & 0.1126 & Trace elements & 0.0084 & 0.0085 \\
$\mathrm{MoO}(\%)$ & 0.0318 & 0.0868 & & & \\
\hline
\end{tabular}

Table 11: Maximum dry density and California Bearing Ratio values corresponding to the design space points /

\begin{tabular}{llc}
\multicolumn{2}{c}{ lattice } & \\
\hline S/N & Properties & Results \\
\hline 1 & Colour & Gray \\
2 & Percentage Passing ASTM D 422 Sieve No.200 (BS Sieve 75 $\mu \mathrm{m}=0.075 \mathrm{~mm}$ & 45.3 \\
& sieve size) & 33 \\
3 & Liquid Limit (\%) & 10.6 \\
4 & Plastic Limit (\%) & 22.4 \\
5 & Plasticity Index (\%) & 2.6 \\
6 & Specific Gravity & $\mathrm{A}-7-5$ \\
7 & AASHTO Classification & $\mathrm{CH}$ \\
8 & Unified Classification System & \\
9 & Major Clay Mineral Present & 1.7 \\
10 & Maximum Dry Density (kg/m ${ }^{3}$ ) & $19 \%$ \\
11 & Optimum Moisture Content (\%) & $6.5 \mathrm{KN}$ \\
12 & California Bearing Ratio & $4.5 \%$ \\
13 & Natural Moisture content & $2.6 \%$ \\
14 & Specific gravity & \\
\hline
\end{tabular}

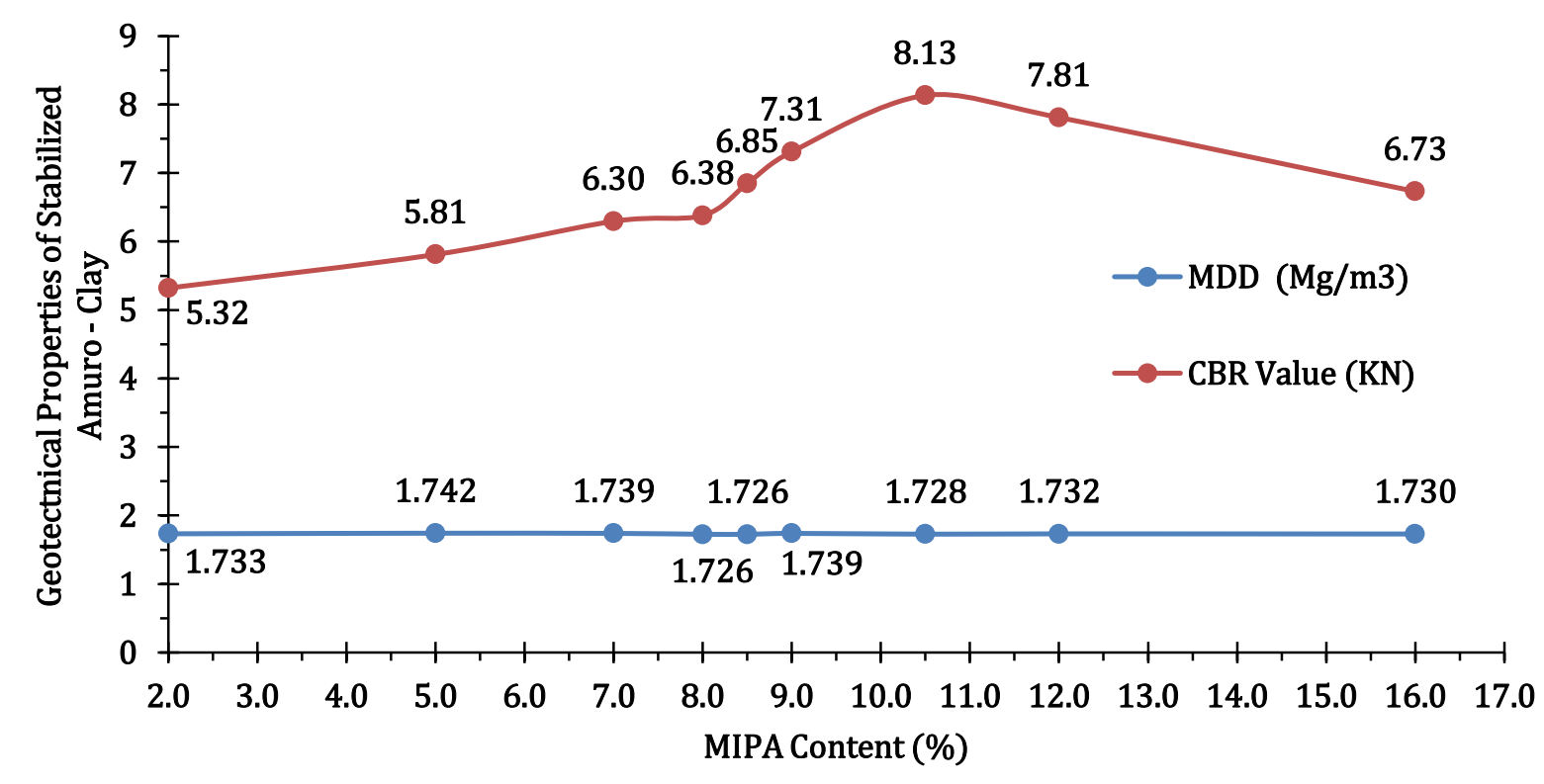

Figure 7: MIPA - Amuro - Subgrade Geotechnical Properties relationship 
Table 12 shows the responses of the stabilized soil in the increasing order of MIPA additive to the soil. Figure 7 clearly shows these responses variation with the addition of the MIPA.

It is seen in Figure 7 that the addition of male efflorescence of palm ash MIPA resulted to an increase in CBR value of Amuro - subgrade. However, there is little or no effect on MDD. These structural properties changes are also observed with the results of the models. The decrease in MDD when MIPA is increased is traced to the pozzolanic characteristics of MIPA; and its finer solid content.

Table 12: Response Variations of MIPA - Amuro stabilized subgrade

\begin{tabular}{ccc}
\hline Ash & MDD $\left(\mathrm{Mg} / \mathrm{m}^{3}\right)$ & CBR Value $(\mathrm{KN})$ \\
\hline 0.0 & 1.734 & 6.21 \\
2.0 & 1.733 & 5.32 \\
5.0 & 1.742 & 5.81 \\
7.0 & 1.739 & 6.30 \\
8.0 & 1.726 & 6.38 \\
8.5 & 1.726 & 6.85 \\
9.0 & 1.739 & 7.31 \\
10.5 & 1.728 & 8.13 \\
12.0 & 1.732 & 7.81 \\
16.0 & 1.730 & 6.73 \\
\hline
\end{tabular}

CBR and MDD values in the experimental and Scheffe's model in the control possess less than 3\% difference. This justifies that the models developed for them are satisfactory. Further, for 5\% significance value, $\alpha, \mathrm{N}=3$ and degree of freedom, $\mathrm{v}_{\mathrm{e}}=\mathrm{v}_{1}=\mathrm{v}_{2}=2$; the $\mathrm{t}$ - value obtained from the standard statistical table, $t_{(\alpha / N)}\left(v_{e}\right)$ is 5.78. This value is greater than those of the $t$ - values obtained in the experimental and model results of the control experiment. Hence, the Null hypothesis is accepted and the model is adequate. This means that there is no significant difference between results of the experiment and the models developed for MIPA Amuro subgrade stabilization.

Similarly, the F- value obtained from the standard statistical table, is 19.00 . This value is greater than those of the $F$ - value obtained between the experimental results and model results in an independent control experiment for CBR response. It slightly differed for MDD response towards the right extremum. The deviation is however minor, as the left extremum condition is very satisfactory. Hence, the slight inconsistency is allowed, having been satisfied by the Student's $t$ - Test. The inverse of this statistical $F-$ value is 0.0526 , which is also smaller than any of the $F-$ value results obtained. Hence, the Null hypothesis is again accepted and the model is adequate.

In the CBR results, as shown in Figure 3, 10.5\% MIPA content in the soil gives the greatest strength (CBR value) of $8.13 \mathrm{KN}$, which is about $31 \%$ increase in strength from $6.21 \mathrm{KN}$ of natural CBR. Hence, this strength started reducing on further addition of MIPA. This suggests that the optimum strength of the soil would be achieved between 10\% - 11\% MIPA content and its peak is at $10.5 \%$ MIPA content for MIPA - Amuro subgrade stabilization.

\section{CONCLUSION}

Frequent failure of Amuro - Okigwe road may not be unconnected with the constituent subgrade formation, the Imo - Clay Shale Formation. This subgrade which is the foundation of the flexible pavements is expansive with its inherent engineering characteristics. In this paper, the subgrade was successfully stabilized using an incinerated vegetable fibre waste from palm oil, known as Male inflorescence of oil palm ash, MIPA collected from Okwe, in Onuimo Local Government Area, Imo State. The material as a stabilizer reflected over $30 \%$ increase in natural CBR value of Amuro - subgrade. Scheffe's second degree mixture model was developed for determine the mixture proportion ratio and maximum dry density and California bearing ratio responses of the soil.

These models developed fit very well in predicting these responses characteristic of MIPA and Amuro subgrade in soil improvement requirements, as they satisfy the significance level of differences with standard statistical requirements.

\section{REFERENCES}

[1] "Lone Star Paving," 3 October 2018. [Online]. Available: https://www.lonestarpavingtx.com/.

[2] I. N. Obeta and J. E. Njoku, "Durability of flexible pavements: a case study of South Eastern, Nigeria," Nigerian Journal of Technology (NIJOTECH), vol. 35, no. 2, pp. 297 - 305, April 2016.

[3] C. N. Okereke, N. N. Onu, C. Z. Akaolisa, D. O. Ikoro, S. I. Ibeneme, B. Ubechu, E. S. Chinemelu and L. O. Amadikwa, "Mapping Gully erosion using remote sensing technique: $\mathrm{A}$ case study of Okigwe area, Southeastern Nigeria," International Journal of Engineering Research 
and Applications, vol. 2, no. 3, pp. 1955 - 1967, 2012.

[4] S. O. Onyekuru, P. O. Iwuoha, C. J. Iwuagwu, K. K. Nwozor and K. D. Opara, "Mineralogical and geochemical properties of clay deposits in parts of Southeastern Nigeria," International Journal of Physical Sciences, vol. 13, no. 14, pp. 217 - 229, 30 July 2018.

[5] J. W. S. de Graft-Johnson, H. S. Bhatia and S. L. Yeboa, "Geotechnical Properties of Accra shales," in Proc. 8th Int. Conf. Soil Mech. Found. Eng., Moscow, 1973.

[6] J. Manasseh and I. O. Agbede, "Cement stabilization of Igumale shale lime admixture for use as flexible pavement construction material," EJGE, vol. 15, pp. 1661 - 1673, 2010.

[7] R. M. Brooks, "Soil stabilization with flyash and rice husk ash," International Journal of Research and Reviews in Applied Sciences, p. 209 - 217, 2009.

[8] H. F. Winterkorn and S. Pamukcu, "Soil stabilization and Grouting," In Foundation Engineering Handbook, 2nd ed., New York, Van Nostrand Reinhold, p. 317, 1991.

[9] K. R. Arora, Soil Mechanics and Foundation Engineering, New Delhi: Standard Publishers Distributers, 2008.

[10] K. Ghavami, "Non-conventional Materials and Technologies: Applications and future tendencies," Bath, 2009.

[11] S. A. Ola, "Geotechnical properties of the Sokoto soft clay shale of northern -western, Nigeria," Tropical Soils of Nigeria in Engineering Practice, vol. 1, pp. 131 - 144, 1983.

[12] K. J. Osinubi, "Evaluation of admixture stabilization of Nigeria black cotton soil," Nigerian Society of Engineers Technical Transactions, vol. 34, no. 3, pp. 88 - 96, 1999.

[13] R. K. Katti and A. R. Katti, Behaviour of saturated expansive soil and control methods, New Delhi: Oxford and IBH, 1994.

[14] O. A. D. Osula, "Evaluation of admixture stabilization for problem laterite," Journal of
Transportation Engineering, vol. 115, no. 6, p. $674-687,1989$.

[15] S. Arora and A. H. Aydilek, "Class F Fly-AshAmended Soils as Highway Base Materials," ASCE Journals of Materials, vol. 17, no. 6, pp. 640 - 649, 2005.

[16] W. H. Chandler, Evergreen orchards, Philadelphia: Lea and Febiger, 1958.

[17] H. Adam, M. Collin, F. Richaud, T. Beulé, D. Cros , A. Omoré, L. Nodichao, N. Bruno, B. Nouy and J. W. Tregear, "Environmental regulation of sex determination in oil palm: current knowledge and insights from other species," Annals of Botany, vol. 108, no. 8, p. 1529 1537, 1 December 2011.

[18] T. E. Kowalski and D. W. Starry, "Characterization and improvement of soils and materials session," in 2007 Annual Conf. of the Transportation Association of Canada, Saskatchewan, 2007.

[19] O. A. Oguaghamba and M. E. Onyia, "Modified and generalized full cubic polynomial response surface methodology (RSM) in engineering mixture design," Nigerian Journal of Technology Vol. 38, No. 1, pp. 52 - 59, January 2019.

[20] O. A. Oguaghamba and B. O. Mama, "Generalized Scheffe's second degree mathematical models approach in engineering mixture design," in 16th Intern. Conf. \& AGM of Nigerian Institute of Civil Engineers on Transforming National Economy through Sustainable Civil Engineering Infrastructures Engineering Solutions to Problematic Soils and Allied Construction Materials, NICE 2018, Calabar, October $24-26,2018$, pp. 32-44.

[21] H. Scheffe, "Experiments with Mixtures," Journal of Royal Statistical Society, vol. 20, no. B, pp. 344 - 360, 1958.

[22] NiMet, The Nigerian Meteorological Agency, 2014.

[23] C. Dougherty, Introduction to Econometrics, 2nd ed., Oxford: Oxford University Press, 2002. 